\title{
Behind the atomic curtain
}

Hans A. Bethe

Stalin and the Bomb: The Soviet Union and Atomic Energy, 1939-1956. By David Holloway. Yale University Press: 1994. Pp. 464. \$30, £19.95.

IN 1945 we speculated that it would take the Russians about five years to develop an atomic bomb. The Soviet test came in August 1949, just about on time, but we did not know how they did it.

David Holloway found out. He made many trips to Russia, reading the nowavailable reports from the project that were compiled during and after the Second World War, and talking to many Russian scientists. He has produced a monumental work, with more than 2,000 references and notes. It makes fascinating reading and will remain the standard work on the subject for many years. What makes it particularly intriguing is that it clears up many previously unanswered questions. Many people have wondered, for instance, whether the nuclear arms race could have been avoided if the Americans or the British, or both, had acted appropriately. By studying Stalin's thinking, Holloway shows that such avoidance would have been impossible.

The centre for physics research in Russia in the 1930s was Ioffe's Institute in Leningrad. Igor Kurchatov, who would head the Soviet bomb effort, joined the institute in the early $1930 \mathrm{~s}$, where he worked in nuclear physics. In 1934, impressed by Enrico Fermi's work with neutrons, he specialized in neutron physics. The discovery of fission in 1938 caused great excitement among Russian scientists; Georgii Flerov, one of Kurchatov's collaborators, was the first to observe spontaneous fission, whereas Yulii Khariton and Yakov Zel'dovich developed the theory of the chain reaction. However, a problem for the Russian researchers was that very little uranium was available.

The Germans invaded the Soviet Union in June 1941. The Ioffe Institute was moved to Kazan; most of its members were recruited for war work. Fission work was discontinued. The British government, however, was taking the chain reaction most seriously, and appointed the Maud committee to analyse the situation. The committee, which included Britain's leading nuclear scientists, reported in July 1941 and recommended a determined effort to use the uranium chain reaction. The difficult isotope separation was to be accomplished by thermal diffusion. Spies

reported the conclusions of the Maud report to Russia around September 1941. In March 1942 Lavrentii Beria, the Soviet secret-police chief, told Stalin of the findings. Long consultations with scientists followed. Kurchatov was appointed to head a chain-reaction project; he was to report to Mikhail Pervukhin. The goahead came from Stalin in January 1943, after the battle of Stalingrad had turned in favour of the Soviets.

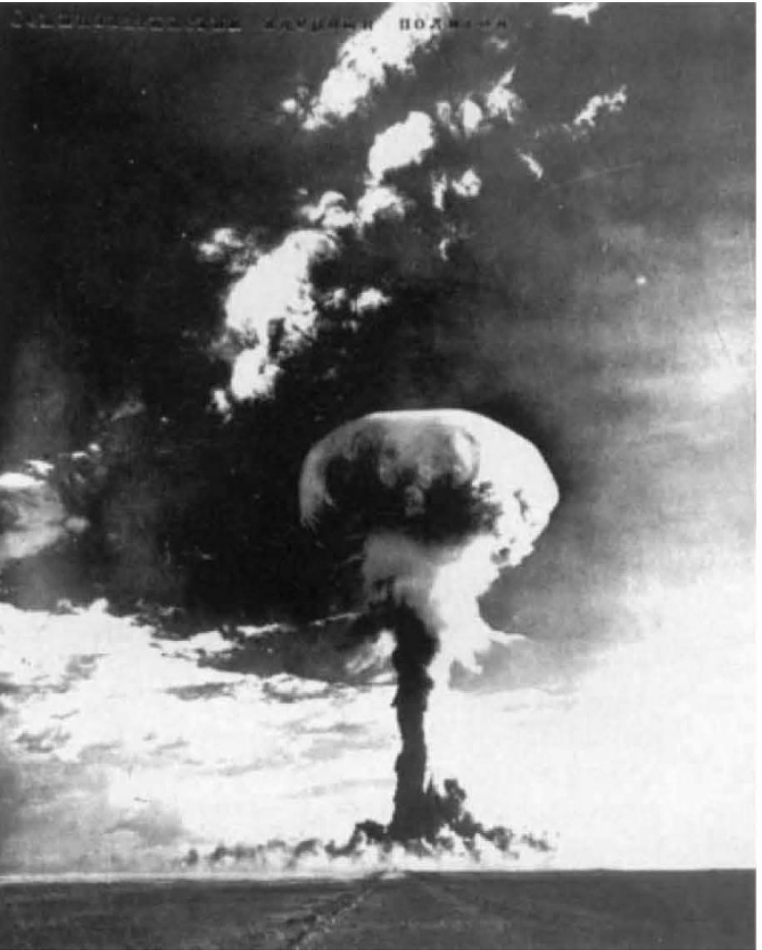

The Soviet hydrogen bomb test of 12 August 1953. This bomb was developed by the Soviets entirely independently, without espionage.

In March 1943 Kurchatov was shown the intelligence reports from Britain. On 7 March he reported to Pervukhin that a strategy similar to the British one was exactly what was needed. The British hoped that a slow-neutron chain reaction could be obtained with natural uranium in graphite, and Fermi was working on this task in Chicago. There was no mention that he had already succeeded on 2 December 1942, and Kurchatov asked intelligence urgently to find out the status of Fermi's work. The British report mentioned the use of plutonium. In 1943 Klaus Fuchs reported from Britain details about isotope separation. Fuchs went to the United States in December 1943. The espionage in
Britain was vital to the Soviet scientists.

Kurchatov was not allowed to tell his colleagues about the British information. With them, however, he planned a chainreaction programme. He took charge of the experimental 'pile' of uranium. He decided to use graphite; $50-100$ tons of uranium would be needed to make the pile go critical. An exponential pile was designed by January 1944, and a cyclotron was brought from Leningrad and assembled by September 1944. By irradiating uranium, the first plutonium was produced. Kurchatov requested $100 \mathrm{~kg}$ of uranium oxide and metal from Lend Lease in Washington; the request was approved by General Leslie Groves, the head of the Manhattan Project, and the materials delivered in 1943. Later Kurchatov acquired about $300 \mathrm{~kg}$ from occupied Germany. Although these were minuscule amounts for building a reactor, they were vital for experimentation.

Theoretical work was started under the leadership of Khariton. Fuchs, now at Los Alamos, provided basic data about the spontaneous fission of plutonium-240, the need for implosion to assemble the plutonium bomb and the need for explosive lenses. In June 1945 he fully described the plutonium bomb, including a sketch and all important dimensions. He wrote that the expected energy yield was 10 kilotons. Kurchatov reported that the data from Fuchs had enormous significance.

As the Soviet army advanced into central Europe, the Czech president, Edvard Beneš, signed an agreement allowing Soviets to mine uranium in Czechoslovakia. Several important German scientists joined the Russian project.

In July 1945, at the Potsdam Conference, President Harry Truman told Stalin that the United States had a weapon of unprecedented power that it would use against Japan. On 6 August the US Air Force dropped an atomic bomb on Hiroshima. On 8 August the Soviet Union attacked Japan's Manchurian army, defeating it easily. Stalin had promised to enter the war against Japan at about this time, but now the Soviet involvement embarrassed the United States.

After Hiroshima, Stalin immediately ordered an all-out effort in the building of Russia's atomic bomb. He put Beria in charge of the project, and told Kurchatov that cost was no object. Holloway makes it clear that Stalin would not have changed his attitude if the United States had followed the advice that Niels Bohr had given in 1944 and had told the Soviets earlier about the existence of the US British project. 
Nor was Stalin's mind altered by the Acheson-Lilienthal plan to internationalize all nuclear developments. This plan was presented to the United Nations by the US statesman Bernard Baruch, who added some features that made it less acceptable to the Soviets. But even without these features, the Soviets would have rejected the plan: Stalin simply wanted his own bomb.

Stalin and Beria were suspicious of almost everyone. They distrusted their own scientists in the atomic project, including Kurchatov; their own intelligence service and spies such as Fuchs; and the official US account of the uranium project, the Smyth report. After all, they asked, why should a country such as the United States publish all the steps leading to an atomic bomb?

Because of these suspicions, Beria sent Yakov Terletskii, a physicist and a member of the NKVD (Soviet police and secret police) to meet Bohr. Bohr, who announced the visit to both the Danish and the British governments, did not tell Terletskii anything beyond what was in the Smyth report, and Terletskii considered the trip to be a failure. But Beria thought it was a success, and in a letter to Stalin (recently published) he enumerates some technical points in the Smyth report, presenting them as if they had come from Bohr.

The Soviet uranium project was a remarkable technical achievement. Industry in the European part of Russia had been largely destroyed during the Second World War, but the industrial plants for plutonium production were built up in record time. Pure graphite was obtained by the end of 1945 , uranium metal by the summer of 1946. The experimental reactor went critical on 25 December 1946. Kurchatov himself directed the approach to criticality, just as Fermi had done in 1942. Beria was not impressed; he still suspected that Kurchatov was deceiving him.

Assembly of the production reactor was started in March 1948; the reactor went critical in June 1948. Chemical separation of plutonium was achieved by precipitation. The project employed 20,000 to 30,000 people in production, 50,000 to 60,000 in construction and about 350,000 in mining. Mining and construction were done largely by prisoners. To prepare for the actual assembly of a bomb, a new laboratory was created, $60 \mathrm{~km}$ south of Arzamas; it was named Arzamas-16, and directed by Khariton.

Khariton and Zel'dovich repeated the
US calculations. Others in the laboratory repeated the experiments on implosion, a difficult task because Soviet electronics was far behind the Americans'. Explosive lenses were made - the Institute of Chemical Physics had much experience with explosives. The difficult problem of detonating all lenses simultaneously was solved to the same accuracy as in the United States.

There was the strictest secrecy in Arzamas. Reports were often written by hand and code words were used. Arzamas naturally was dubbed Los Arzamas. There was

do this was scheduled for 21 March 1949. Fortunately, Kurchatov was consulted and said: "If quantum theory and relativity are eliminated, there cannot be any atomic bomb." Stalin accepted Kurchatov's opinion and cancelled the conference, five days before it was to begin. "We can always shoot them later", he said.

The hydrogen bomb was developed by the Soviets entirely independently, without espionage. The main inventor was Andrei Sakharov. His first idea was to use a "layer cake" with alternating layers of uranium-235 and deuterium. Vitalli Ginzberg had the second
idea, namely to supply deuterium in the form of solid lithium deuteride. A device using these two ideas was tested in August 1953 and gave a yield of 400 kilotons. Then Sakharov had a third idea, radiation implosion, the same as the US principle originated by Teller and Ulam. This was tested on 22 November 1955, with a bomb dropped from an airplane. It gave a yield of 1.6 megatons, the yield being kept low to permit the plane to escape undamaged. According to Sakharov's memoirs, the test "essentially solved the problem of high-performance thermonuclear weapons".

a spirit of cooperation similar to that at Los Alamos. All scientists believed that the Russian bomb was necessary.

It took four years to build the bomb, just about the same as the US project. The United States had the advantage of being a fully functioning country, whereas Russia was largely destroyed. On the other hand, the Soviets had information from Fuchs that allowed them to bypass many difficulties. Fuchs thought he had saved the Soviets four to five years of work; it was more likely two to three.

Enough plutonium was ready before uranium-235, and the Russians had a complete design of the US plutonium explosive from Fuchs, so plutonium was chosen for the first test. The test took place on 29 August 1949 at Semipalatinsk, with Kurchatov in command. It was a complete success. Kuchatov wrote the report by hand. Receiving it, Stalin said: "There will not be war." Big rewards went to the scientific leaders, the most important of whom were declared "heroes of socialist labour", the highest distinction.

The Soviet bomb project had one very good side-effect. Tofim Lysenko had destroyed Soviet genetics. He and others now wanted to make physics also conform to Soviet ideology. Relativity theory and quantum theory were to be declared counter-revolutionary. A big meeting to
The Soviet test came 20 months after the US test of deliverable hydrogen bombs. The Soviets got no help from the US test of November 1952; although they had collected fallout in the snow, the sample was inadvertently poured down the drain by a chemist.

The General Advisory Committee to the US Atomic Energy Commission had tried in 1949 to prevent the hydrogen bomb by proposing to the Russians a treaty pledging both sides to refrain from its development. Sakharov and Khariton both believe that Stalin would never have accepted this.

After Hiroshima, President Truman and Secretary of State James Byrnes tried atomic diplomacy, but it was a failure. Stalin refused to be impressed; in fact, he pursued a confrontational policy. In the end, his policy led to the 1947 Marshall Plan for the postwar reconstruction of Europe.

After Stalin's death in March 1953, his successors remained committed to nuclear weapons. For instance, they declared surface ships obsolete in nuclear war. Like the Americans, the Soviets developed tactical weapons and instructed the military about nuclear war. Stalin's successors nevertheless pursued the idea of "peaceful coexistence" with the capitalists. At the Twentieth Party Congress in 
January 1956, Khrushchev declared that there was a choice between peaceful coexistence and the most destructive war in history.

Khrushchev was impressed by the 1955 test of the improved hydrogen bomb. East and West now shared an understanding that nuclear war was unacceptable, and they knew that the other side understood this too. At last Bohr's dream was realized that statesmen should appreciate that nuclear weapons are a mortal danger to the world and are not weapons of war.

I can give here only a bare outline of Holloway's book. There is a lot more in it. For instance, he gives a detailed, vivid account of the Soviet-US confrontation in atomic policy, how it led to the Marshall Plan, to the establishment of the Federal Republic of Germany and its currency and to the Berlin blockade and airlift - all of it based on extensive documentation. Holloway is also good on the Korean War and the related discussions in the Soviet Union, and tells of the fate of well-known Soviet scientists.

This is a must read for all who are interested in the influence of atomic weapons policy, the early Cold War or the interplay of technical competence and espionage, as well as those simply looking for a splendid detective story.

Hans A. Bethe is in the Newman Laboratory of Nuclear Studies, Cornell University, Itha ca, New York 14853-5001, USA. During the Second World War he was director of the theoretical physics division of the Los Alamos Atomic Scientific Laboratory.

\section{Best of British}

\section{F. H. Hinsley}

Test of Greatness: Britain's Struggle for the Atom Bomb. By Brian Cathcart. John Murray: 1994. Pp. 301. £19.99.

THE first British nuclear bomb was successfully exploded on 3 October 1952 in the Monte Bello islands off the northwest coast of Australia. This was the outcome of a programme - Brian Cathcart rightly calls it a struggle - that was propelled by a series of decisions stretching back to the second half of 1945. The decisions, which were so secret that the prime minister, Clement Attlee, did not consult or even inform his cabinet except for a few leading ministers (the Australian prime minister, Robert Menzies, followed suit), were prompted by the unilateral termination by the United States of the cooperation with Britain in the Manhattan Project which had produced the bombs dropped on Hiroshima and Nagasaki.

There were other considerations. A research programme seemed necessary if
Britain was to participate in the establishment of some system of international control of atomic energy, although the prospects of success were judged to be faint. Far stronger was the expectation that the Soviet Union would soon produce a bomb: the defector Igor Gouzenko disclosed in September 1945 that Alan Nunn May had passed information about the Manhattan Project to Moscow. Together with the realization that, as Attlee wrote within days of the explosions over Japan, the bomb had made nonsense of all previous thinking about the defence of Britain, these were the arguments that led to a rapid if not quite complete consensus behind the conclusion voiced in 1951 by William Penney, head of the team of scientists who designed the British bomb: "the discriminative test for a first-class power is whether it has made an atomic bomb". Ernest Bevin, the foreign secretary, is said to have made the point more colourfully in October 1946 to a cabinet committee dismayed at the estimated cost: "We've got to have this thing... whatever it costs.... We've got to have a bloody Union Jack flying on top of it."

A comprehensive account of these central political and strategic decisions, as also of the organizational, technological, financial and manpower problems to which they gave rise, and of how they were solved, was published in 1974 in the second volume of Margaret Gowing's official history, Independence and Deterrence: Britain and Atomic Energy, 1945-52. Cathcart provides a lucid summary of the official account and occasionally amplifies it where newly declassified documents allow. But decisions and developments at the higher levels, while they form the essential scaffolding for his book, are not his main concern. That is to relate how the project was brought to fruition at the workface, his prime sources the recollections of a wide cross-section of the scientists assembled by Penney to staff High Explosive Research, forerunner of the Atomic Weapons Research Establishment at Aldermaston, and of the representatives from the Royal Air Force, the Royal Navy and the Royal Engineers who were directly associated with them; and as these men have recently become free to discuss their experiences - although still within certain security constraints - the result is an original and absorbing contribution to our knowledge.

The team included none of the country's foremost scientists. Penney set his sights on making a near approximation to the plutonium implosion bomb used against Nagasaki, of which he had acquired general knowledge at Los Alamos and as an observer of its effects from the air and on the ground. For this he needed not a reconstitution of the British Los Alamos team, but technologists and technicians. More than half of them were in their 20s. They were, however, forced to work at and beyond the frontiers of their technological experience in chemistry and chemical engineering, nuclear physics, radiology, medicine and above all metallurgy. The refusal of the US authorities to provide information and material was offset by assistance from some of the British Los Alamos veterans. Notable among them was Klaus Fuchs; he had close knowledge of the Nagasaki weapon and, now head of theoretical physics at the Atomic Energy Research Establishment at Harwell, he placed this knowledge at Penney's disposal until in January 1950 he confessed that he had also assisted the Soviet Union, whose first nuclear test had recently been detected, and was jailed for treason.

Cathcart is not himself a scientist, and he has taken pains to make his account accessible, as literary critics say, to readers who labour under the same disadvantage. If the book has a fault it is that, between the fascinating story of the making of the bomb and the final drama of the test itself, it covers in equally great detail other matters, such as the transfer of the scientists and their equipment to Monte Bello and the preparations and rehearsals on the islands for the explosion, of which day-today and sometimes hour-to-hour accounts are bound to become tedious. But even this is a fault in the right direction: it completes the story and enhances its realism.

Eighty-five of the scientists and most of the equipment made the passage in cramped warships, and the voyage round the Cape took 59 days, 37 of them at sea. The Monte Bello islands held few species of wildlife and even fewer charms; and it causes no surprise to learn that hitches were frequent in the final preparations for so complex an undertaking in such hostile terrain. The truly serious hitch, not unlike that which had delayed and threatened to abort the Normandy landings in 1944, came at the end. If a lull in the unstable weather had not permitted a postponed explosion on 3 October, Cathcart doubts whether the expedition could have waited for the next suitable period.

$\mathrm{He}$ ends on an elegiac note. The success of the test marked only the entry of Britain into a race of indefinite duration - a race in which it was able to surmount the hurdle of the hydrogen weapon, a device first exploded by the United States in November 1952, but was thereafter outpaced by the development of ever more sophisticated delivery systems. He has no doubt, however, that Britain's decision to join in the race was justified, and he demonstrates that its success in doing so was a magnificent achievement.

Sir Harry Hinsley is at St John's College, Cambridge CB2 1TP, UK. During the Second World War he worked in the UK Government Code and Cypher School. 